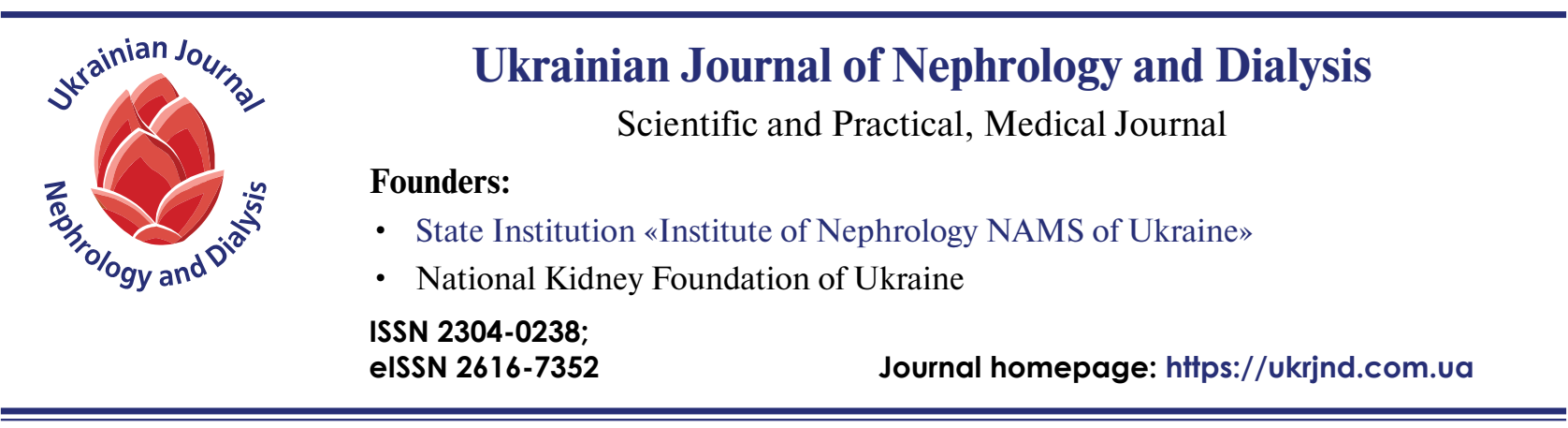

\section{Original Papers}

doi : 10.31450/ukrjnd.3(71).2021.05
I. O. Dudar' ${ }^{1}$ E. K. Krasjuk ${ }^{2}$, Y. I. Honchar ${ }^{1}$, O. M. Loboda ${ }^{1}$, I. M. Shifris ${ }^{1}$, V. F. Krot ${ }^{1}$, V. M. Savchuk ${ }^{2}$

\title{
The use of epoetin alfa biosimilar in the anemia management in
} hemodialysis patients

${ }^{1} \mathrm{SI}$ «Institute of Nephrology NAMS of Ukraine», Kyiv, Ukraine

${ }^{2} \mathrm{MNE}$ «Kyiv City Center of nephrology and dialysis», Kyiv, Ukraine

\section{Citation:}

Article history:

Received February 26, 2021

Received in revised form

June 27, 2021

Accepted June 28, 2021
Dudar I, Krasjuk E, Honchar Yu, Loboda M, Shifris I, Krot V, Savchuk V. The use of epoetin alfa biosimilar in the anemia management in hemodialysis patients. Ukr J Nephr Dial. 2021;3(71):36-43. doi: 10.31450/ukrjnd.3(71).2021.05.

Abstract. The present study aimed to evaluate the efficacy and safety of EMAVAIL (epoetin alfa) in the correction of anemia in hemodialysis patients.

Methods. A total of 36 patients undergoing regular hemodialysis were enrolled in this prospective study. Among the patients were 19 (53\%) men and 17 (47\%) women with severe anemia (hemoglobin $(\mathrm{Hb})$ level $\leq 90 \mathrm{~g} / \mathrm{L}$ ). The mean patients' age was $48.41 \pm 1.82$ years, an average dialysis vintage consisted of $42.38 \pm 10.41$ months. All the patients had thrice-weekly hemodialysis sessions, with a mean duration of $12.6 \pm 0.51$ hours per week and Kt/V $1.27 \pm$ 0.08. All the patients were treated with biosimilar of epoetin alfa EMAVAIL intravenously three times a week in adjustable doses. The follow-up period was 56 days.

Results. At the study entry, the mean Hb level in hemodialysis patients was $81.7 \pm 0,93 \mathrm{~g} / \mathrm{L}$. In 56 days of anemia treatment, the concentration of $\mathrm{Hb}$ increased to $109.17 \pm 1.75 \mathrm{~g} / \mathrm{L}$. Eventually, $32(89 \%)$ patients achieved the target $\mathrm{Hb}$ level $(110 \mathrm{~g} / \mathrm{L}) ; 6(17 \%)$ patients had adverse events (mild hypertension). There were no serious adverse events.

Conclusions. EMAVAIL is an effective and safe epoetin alfa biosimilar for anemia management in hemodialysis patients.

Key words: chronic kidney disease, anemia, hemodialysis, epoetin alfa, hemoglobin.

Conflict of interest statement. The authors declare no competing interest.

(C) Dudar I., Krasjuk E., Honchar Yu., Loboda M., Shifris I., Krot V., Savchuk V., 2021. All rights reserved.

Correspondence should be addressed to Iryna Dudar: irina_d@ukr.net 
(С Дудар I. О., Красюк Е. К., Гончар Ю. І., Лобода О. М., Шіфріс І. М., Крот В. Ф., Савчук В. М., 2021 УДК: 616.61-085.38-073.27:616.155.194]-08

І. О. Дудар ${ }^{1}$, Е. К. Красюк ${ }^{2}$ Ю. І. Гончар ${ }^{1}$, О. М. Лобода ${ }^{1}$, I. М. Шіфріс ${ }^{1}$, В. Ф. Крот ${ }^{1}$, В. М. Савчук ${ }^{2}$

\title{
Застосування біоаналогу епоетину альфа для корекції анемії у пацієнтів з хронічною хворобою нирок VД стадії, які лікуються методом гемодіалізу
}

\author{
${ }^{1}$ ДУ «Інститут нефрології НАМН України», м. Київ \\ ${ }^{2}$ КНП «Київський міський центр нефрології та діалізу»
}

Резюме. Метою роботи була оцінка ефективності та безпеки препарату EMAVAIL (епоетин альфа) у корекції анемії у пацієнтів з хронічною хворобою нирок ИД стадії, які лікуються методом гемодіалізу.

Матеріали та методи. У поточне проспективне дослідження включено 36 пацієнтів, які лікуються гемодіалізом та анемією з рівнем гемоглобіну $\leq 90$ г/л. Серед включених пацієнтів було 19 (53\%) чоловіків та 17

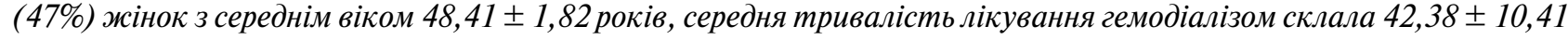
місяия. Усі пацієнти отримували гемодіаліз 3 рази на тиждень; середня тривалість діалізної терапії становила $12,6 \pm$ 0,51 годин на тиждень, середнє Kt/V 1,27 0 0,08. Усі пацієнти отримували ЕМАVAIL внутрішньовенно три рази на тиждень відповідно до інструкції виробника. Тривалість лікування склала 56 днів.

Результати. Середній рівень гемоглобіну пацієнтів на момент включення у дослідження становив 81,70 \pm 0,93 г/л, через 56 днів лікування збільшився до 109,17 1 1,75 г/л. 32 (89\%) пацієнтів досягли цільового рівня гемоглобіну (110 г/л); 6 (17\%) хворих мали побічні ефекти у вигляді помірної гіпертензії. Серйозних небажсаних явищ, не було.

Висновок. ЕMAVAIL є ефективним і безпечним біоаналогом епоетину альфа у корекцї анемії у пацієнтів з хронічною хворобою нирок ИД стадії, які лікуються методом гемодіалізу.

Ключові слова: хронічна хвороба нирок, анемія, гемодіаліз, епоетин альфа, гемоглобін, цільовий рівень

Вступ. Анемія є звичайним наслідком хронічної хвороби нирок (ХХН), її розповсюдженість зростає відповідно стадії ХХН та складає при ХХН VД понад 90\%. За визначенням Всесвітньої організації охорони здоров'я (WHO) діагноз анемії встановлюється за концентрації гемоглобіну (Hb) у крові <12 г / дл для невагітних дорослих жінок і $<13$ г / дл для дорослих чоловіків [1]. Важка форма анемії (гемоглобін <90 г / л) у пацієнтів, які лікуються діалізом, асоціюється зі збільшенням ризику смертності, розвитком кардіо-васкулярних та інфекційних подій, когнітивними розладами, погіршенням якості життя, порушенням фізичного функціонування, депресією [2].

Розвиток анемії у пацієнтів з ХХН взагалі та у діалізних пацієнтів зокрема зумовлюється багатьма факторами, однак основним є зменшення продукції нирками ендогенного еритропоетину, відповідального за стимуляцію проліферації та диференціації еритроїдних клітин в зрілі эритроцити.

Революційним наприкінці $1980-x$ років стало запровадження у лікуванні анемії епоетину

\section{Дудар Ірина Олексіївна} irina_d@ukr.net альфа, розробленого компанією “Amgen”. Цей та пов'язані з ним еритропоез стимулюючі засоби (ЕС3), що були розроблені згодом, принесли велику користь пацієнтам, усунувши виснажливі симптоми тяжкої анемії та звільнивши їх від необхідності переливання крові та пов'язаними з ним ускладненнями (вторинне перевантаження заліза, інфекції та сенсибілізація, що перешкоджає трансплантації). Ефективна корекція анемії безпосередньо знижує захворюваність і смертність хворих, головним чином за рахунок серцево-судинних та інфекційних ускладнень, поліпшує якість життя, підвищує працездатність, збільшує переносимості фізичних навантажень, поліпшує когнітивну та статеву функції $[3,4]$.

Висока ефективність ЕС3 при лікуванні анемії замовила стрімке зростання їх використання протягом минулих років і ця тенденція, на думку спеціалістів, найближчі роки збережеться. Необхідність застосування ЕС3 на цей час є беззаперечною, а епоетин альфа, хоча був першим з цієї групи препаратів, залишається найбільш поширеним [5].

За даними «Національного реєстру хворих на хронічну хворобу нирок та пацієнтів з гострим пошкодженням нирок: 2019 рік» в Україні ЕСЗ отримували 70,6\% пацієнтів, які лікувались програмним гемодіалізом та гемодіафільтрацією. Кількість цих хворих зросла з 3405 в 2013 р. до 7869 в 2019 р., тобто на $61 \%[6,7]$. 
Останні роки у зв'язку із закінченням терміну патентного захисту оригінальних препаратів збільшується кількість біоаналогів епоетину. Дані ряду досліджень демонструють, що біоподібні ЕС3 є такими ж ефективними та безпечними, як і оригінальні ЕС3. Поряд з цим, враховуючи низьку ціну та доступність, вони мають вагомі переваги та заслуговують на більш широке застосування в практиці, що дозволяє заощаджувати значні кошти [8].

Метою дослідження була оцінка ефективності та переносимості біоаналога епоетину альфа EMAVAIL у корекції анемії у пацієнтів з хронічною хворобою нирок VД стадії, які лікуються методом гемодіалізу.

Пацієнти та методи. Робота виконана з дотриманням правил безпеки пацієнтів, збережені права та канони людської гідності, а також морально-етичні норми у відповідності до основних положень GSP (1996 р.), конвенції Ради Європи про права людини та біомедицину (від 04.04.1997 р.), Гельсинської декларації Всесвітньої медичної асоціації про етичні принципи проведення наукових медичних досліджень за участю людини (1964-2000 рр.) і наказу МО3 України №281 від 01.11.2000 р., етичного кодексу ученого України (2009 р.).

Включення пацієнтів до дослідження відбувалось після підписання Інформованої згоди на підставі критеріїв включеня/виключення.

\section{Критерії включення пацієнтів:}

- пацієнти з ХХН VД ст. обох статей віком від 18 до 65 років, які лікуються гемодіалізом понад 3 місяці;
- рівень $\mathrm{Hb} \leq 90$ г/л,;

- підписана Інформована згода пацієнта на участь у дослідженні;

- для жінок репродуктивного віку - негативний тест на вагітність.

\section{Критерії виключення:}

- відома гіперчутливість до досліджуваного препарату;

- неконтрольована артеріальна гіпертензія;

- плановані хірургічні втручання;

- тромбоцитоз, підвищений ризик розвитку тромбозу;

- важка патологія судин (в т.ч. коронарних, церебральних, периферичних);

- інфаркт міокарду або гостре порушення мозкового кровообігу, перенесені менш, ніж за 6 місяців до скринінгового візиту;

- вагітність, лактація;

- прийом препаратів еритропоетину менш, ніж за 4 тижні до скринінгового візиту.

Лабораторне, клінічне обстеження та спостереження проводилось згідно уніфікованих клінічних протоколів «Лікування пацієнтів 3 хронічною хворобою нирок V стадії: проведення інтермітуючого гемодіалізу», «Лікування пацієнтів з хронічною хворобою нирок V стадії з анемією».

Проспективний дизайн дослідження представлено на рис. 1; частоту та об’єм моніторингу подано у Табл. 1.

\begin{tabular}{|l|c|c|c|c|c|}
\cline { 2 - 6 } \multicolumn{1}{c|}{} & \multicolumn{5}{c|}{ ЕМАВЕЙЛ 50 ОД/кг 3 рази на тиждень або доза після корекції } \\
\cline { 2 - 6 } \multicolumn{1}{c|}{} & $\begin{array}{c}\text { Візит 1 } \\
\text { (День 1) }\end{array}$ & $\begin{array}{c}\text { Візит 2 } \\
\text { (День 14) }\end{array}$ & $\begin{array}{c}\text { Візит 3 } \\
\text { (День 28) }\end{array}$ & $\begin{array}{c}\text { Візит 4 } \\
\text { (День 42) }\end{array}$ & $\begin{array}{c}\text { Візит 5 } \\
\text { (День 56) }\end{array}$ \\
\hline $\begin{array}{l}\text { Скринінг (в межах 21 дня } \\
\text { до Візит 1, за необхідності - } \\
\text { СУФЕР®) }\end{array}$ & $\begin{array}{c}\text { Початок } \\
\text { лікування } \\
\text { ЕМАВЕЙЛ }\end{array}$ & Оцінка дози & Оцінка дози & Оцінка дози & Оцінка дози \\
\hline \hline
\end{tabular}

Період лікування ЕМАВЕЙЛ

Рис. 1. Дизайн дослідження

Таблиия 1

Частота та об'єм обстеження включених у дослідження пацієнтів

\begin{tabular}{|l|c|c|c|}
\hline & Скринінг & Візит 1, 2, 3,4 & Візит 5 \\
\hline $\begin{array}{l}\text { Отримання письмової інформованої } \\
\text { згоди }\end{array}$ & $\mathrm{C}$ & & \\
\hline Анамнез & $\mathrm{C}$ & & \\
\hline Об'єктивне обстеження & $\mathrm{C}$ & $\mathrm{X}$ & $\mathrm{X}$ \\
\hline ЕКГ & $\mathrm{C}$ & & $\mathrm{X}$ \\
\hline
\end{tabular}


Продовження таблиці 1

\begin{tabular}{|l|c|c|c|}
\hline & Скринінг & Візит 1, 2, 3, 4 & Візит 5 \\
\hline Лабораторні дослідження: & & & \\
\hline гемоглобін крові & & $\mathrm{X}$ & $\mathrm{X}$ \\
\hline загальний аналіз крові & $\mathrm{C}$ & & $\mathrm{X}$ \\
\hline б / х аналіз крові & $\mathrm{C}$ & & $\mathrm{X}$ \\
\hline $\begin{array}{l}\text { показники обміну заліза } \\
\text { концентрація віт.В12, фолієвої кислоти }\end{array}$ & $\mathrm{X}$ & & \\
\hline $\begin{array}{l}\text { Для жінок репродуктивного віку - тест на } \\
\text { вагітність }\end{array}$ & $\mathrm{X}$ & & $\mathrm{X}$ \\
\hline Реєстрація побічних явищ / реакцій & & $\mathrm{X}$ & $\mathrm{X}$ \\
\hline Оцінка ефективності та переносимості & & & \\
\hline
\end{tabular}

Перед призначенням еритропоетину хворим 3 показниками НСТ (насичення трансферину сироватки) $\leq 30 \%$ та/або ферити $\leq 500$ нг/мл була проведена терапія навантаження: 600 мг елементарного заліза в/в протягом 2-х тижнів. Пацієнти отримували препарат СУФЕР® (заліза (III)-гідроксид сахарозний комплекс), розчин для ін'єкцій 20 мг/мл 5 мл, виробництва ТОВ “Юрія-Фарм” (Україна).

Сумарна коригуюча доза препарату визначалася відповідно до рекомендацій виробника за формулою:

Загальний дефіцит заліза (мг) = маса тіла (кг) - (нормальний рівень $\mathrm{Hb}$ (г/л) - рівень Нb пацієнта $(г / л)) \cdot 0,24+$ депоноване залізо (мг).

Нормальний рівень $\mathrm{Hb}$ - 150 г / л, кількість депонованого заліза - 500 мг. Коефіцієнт 0,24 = 0,0034 • 0,07 • 1000 (вміст заліза в $\mathrm{Hb}=0,34 \%$, об’єм крові $=7 \%$ маси тіла, коефіці-

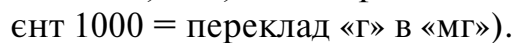

Перед першою крапельною інфузією проводили тест-дозу: вводили 20 мг заліза протягом 15 хв. При відсутності протягом 60 хвилин небажаних явищ вводили з рекомендованою швидкістю частину розчину, що залишилася.

Препарат вводився крапельно 3 рази на тиждень в дозі 200 мг з дотриманням рекомендацій виробника (препарат СУФЕР® розводили в $0,9 \%$ розчині $\mathrm{NaCl}$ у співвідношенні 1:20 та вводили у венозну діалізну магістраль протягом щонайменше 30 хв.).
Лікарський засіб ЕМАВЕЙЛ (епоетин-альфа), розчин для ін'єкцій виробництва Шеньянг Саншайн Фармасьютікал Ко, Лтд. / Shanyang Sunshine Pharmaceutical Co. Ltd., призначався внутрішньовенно після сесії гемодіалізу у дозі 50 ОД/кг 3 рази на тиждень. Курс лікування -8 тижнів.

Корекція дози еритропоетину здійснювалась за наступним алгоритмом:

Гемоглобін підвищується від 10 до 20 г/л за 4 тижні - доза не змінюється до досягнення цільового значення;

Знижена відповідь на препарат (швидкість приросту гемоглобіну менше 10 г/л за 4 тижні) підвищення тижневої дози на $50 \%$.

Підвищена відповідь на препарат (швидкість приросту гемоглобіну більше 10 г/л за 2 тижні) зменшення тижневої дози на $50 \%$.

Ефективність лікування оцінювалась за:

- досягненням цільового рівня Нb в процесі 8-тижневої терапії,

- рівнем Нb після 8-тижневої терапії,

- тривалістю терапії до досягнення цільового значення $\mathrm{Hb}$,

- середньою дозою еритропоетину до досягнення цільового значення $\mathrm{Hb}$.

Складові оцінки ефективності та переносимості ЕМАВЕЙЛ подано у Табл. 2, 3.

\section{Оцінка ефективності лікування ЕМАВЕЙЛ}

\begin{tabular}{|l|l|}
\hline $\begin{array}{l}\text { Препарат } \\
\text { эфективний }\end{array}$ & $\begin{array}{l}\text { При 8-тижневому лікування досягнуто цільове значення } \mathrm{Hb}>100 \text { г/л та рівень } \\
\text { Нb підтримується в межах 100-120 г/л }\end{array}$ \\
\hline $\begin{array}{l}\text { Препарат } \\
\text { неэфективний }\end{array}$ & При 8-тижневому лікування не досягнуто цільове значення $\mathrm{Hb}$ \\
\hline
\end{tabular}




\section{Оцінка переносимості ЕМАВЕЙЛ}

Таблиця 3

\begin{tabular}{|l|l|}
\hline Добра & $\begin{array}{l}\text { При об’єктиному та/або лабораторному обстеженні не виявлені патологічні } \\
\text { зміни або клінічно значимі відхилення } \\
\text { та/або } \\
\text { пацієнт не вказує на прояви побічних реакцій. }\end{array}$ \\
\hline Задовільна & $\begin{array}{l}\text { При об’єктиному та/або лабораторному обстеженні в динаміці виявлені } \\
\text { зміни або клінічно значимі відхилення, котрі мають тимчасовий характер та не } \\
\text { потребують зміни схеми лікування досліджуваним препаратом } \\
\text { та/або } \\
\text { пацієнт не вказує на прояви незначних побічних реакцій, що не призводять до } \\
\text { серьозних проблем та не потребують відміни препарата. }\end{array}$ \\
\hline Незадовільна & $\begin{array}{l}\text { При об’єктиному та/або лабораторному обстеженні в динаміці виявлені } \\
\text { зміни або клінічно значні відхилення, кототрі потребують відміни препарату та } \\
\text { проведення додаткових заходів } \\
\text { та/або } \\
\text { пацієнт вказує на прояви побічних реакцій, що мають значний негативний } \\
\text { вплив на його стан, потребують відміни препарата та застосування додаткових } \\
\text { заходів. }\end{array}$ \\
\hline
\end{tabular}

Результати. Характеристика включених у дослідження пацієнтів подана у Таблиці 4.

Таблиця 4

Загальна характеристика включених у дослідження пацієнтів

\begin{tabular}{|l|c|}
\hline \multicolumn{2}{|c|}{ Причини ХХН } \\
\hline \multicolumn{2}{|c|}{ Вікоків) } \\
\hline Хронічний глормерулонефрит (n, \%) & $23(64)$ \\
\hline Полікістоз нирок & $71 \pm 1,82$ \\
\hline Хронічний пієлонефрит & $3(8)$ \\
\hline Цукровий діабет & $3(8)$ \\
\hline Тривалість лікування ГД (міс.) & $42,38 \pm 10,41$ \\
\hline Годин гемодіалізу на тиждень & $12,6 \pm 0,51$ \\
\hline Кт/V & $1,27 \pm 0,08$ \\
\hline Індекс маси тіла (кг/м2) & $2,41 \pm 4,35$ \\
\hline Систолічний АТ (мм рт. ст.) & $136,89 \pm 2,83$ \\
\hline Діастолічний АТ (мм рт. ст.) & $82,97 \pm 1,22$ \\
\hline Частота серцевих скорочень за хвилину & $81,41 \pm 0,92$ \\
\hline Гемоглобін (г/л) & $81,70 \pm 0,93$ \\
\hline Тромбоцити ( 109/л) & $216,59 \pm 5,37$ \\
\hline Альбумін (г/л) & $40,73 \pm 1,02$ \\
\hline Феритин (нг/мл) & $395,85 \pm 132,46$ \\
\hline \% насичення трансферину & $36,25 \pm 5,17$ \\
\hline
\end{tabular}

Усі 36 пацієнтів пройшли повний 56-денняй курс лікування. Середня тижнева доза ЕМАВЕЙЛ на початку лікування склала 150,48土1,73 МО/кг.

Протягом курсу лікування цільове значення рівня Нb було досягнуто у 32 (89\%) хворих. У
4 (11\%) пацієнтів рівень гемоглобіну не досяг цільового значення. Динаміка відсотку пацієнтів, які досягли цільовий рівень Нь протягом періоду спостереження подана на рис. 2. 


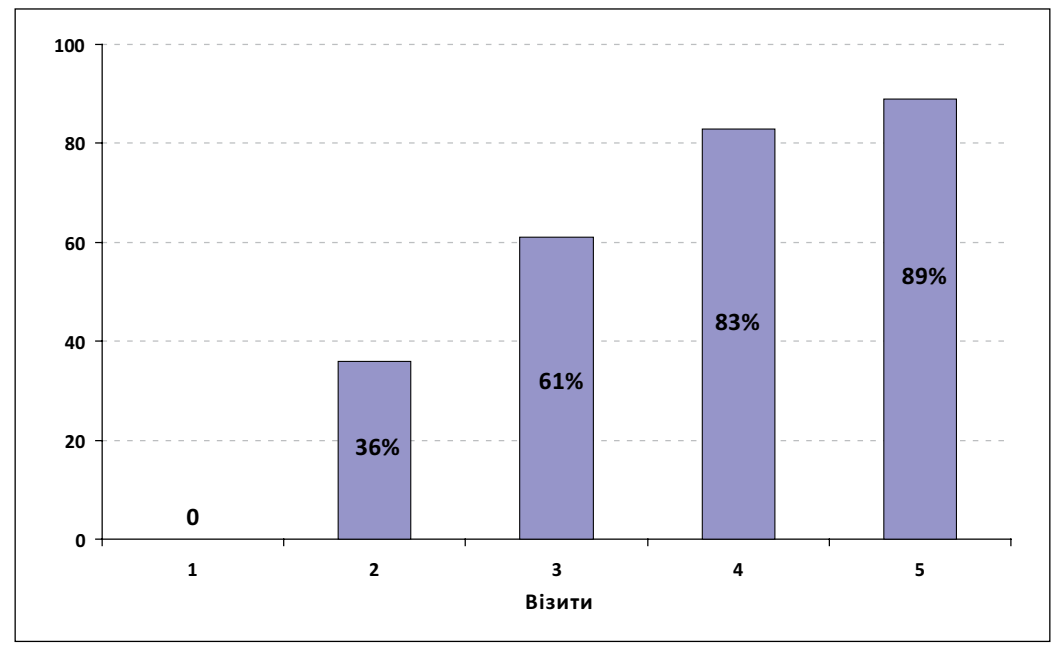

Рис. 2. Динаміка досягнення цільового рівня Нь протягом 56 денного періоду спостереження та лікування.

На рис. 3 представлена динаміка рівня гемоглобіну крові хворих протягом періоду лікування.

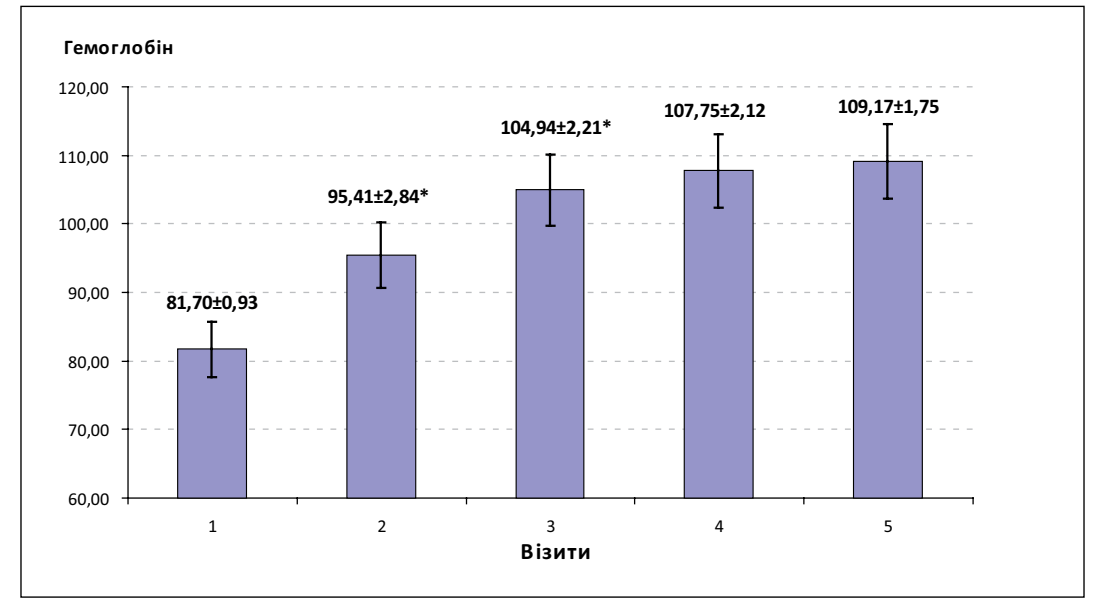

Рис. 3 Динаміка рівня гемоглобіну крові хворих протягом періоду лікування

Примітка: * - достовірна різниця у порівнянні з даними попереднього візиту $(\mathrm{p}<0,05)$

Протягом 56-денного курсу лікування рівень Нb крові збільшився $з$ 81,70 $\pm 0,93$ г/л до $109,17 \pm 1,75$ г/л $(\mathrm{p}<0,001)$, тобто на 27,47 г/л, що складає $33,62 \%$ від вихідного рівня.

Середня тривалість терапії до досягнення цільового рівня Нb склала 28,44 $\pm 2,63$ днів. Середня тижнева доза ЕМАВЕЙЛ у період корекції склала $132,18 \pm 4,81 \mathrm{MO} /$ кг.

Динаміка тижневої дози ЕМАВЕЙЛ у пацієнтів, які досягли цільового рівня Нb крові протягом курсу лікування подана на рис. 4.

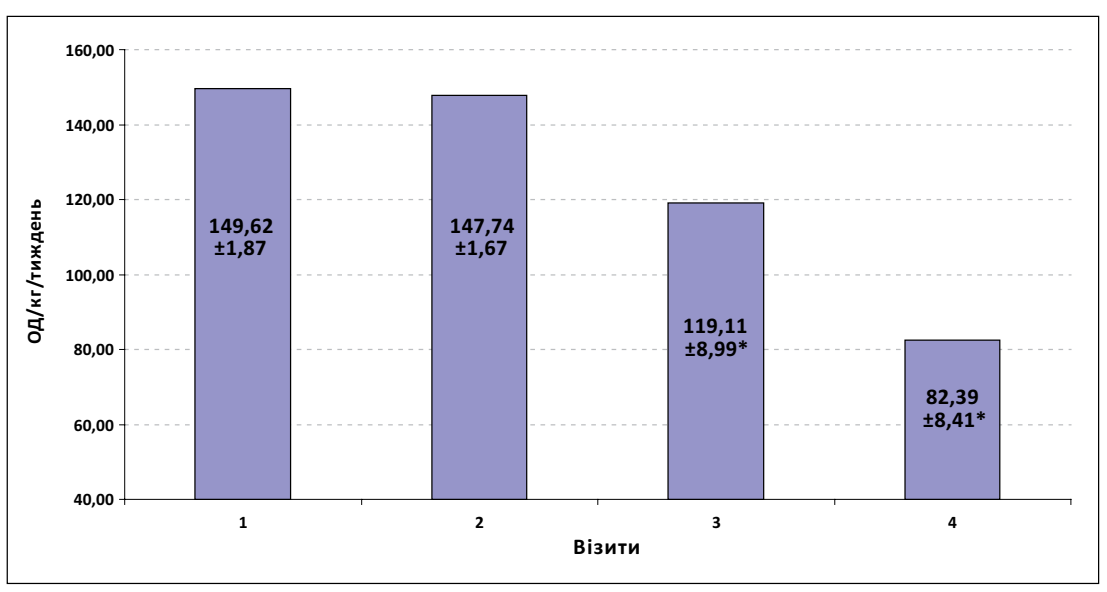

Рис. 4. Динаміка тижневої дози ЕМАВЕЙЛ у пацієнтів, які досягли цільового рівня Нb протягом курсу лікування.

Примітка: * - достовірна різниця в порівнянні з даними попереднього візиту $(\mathrm{p}<0,05)$ 
Аналіз переносимості препарату продемонстрував наступне. Добре переносили препарат 30 хворих (83\%). Задовільна переносимість констатована у 6 пацієнтів (17\%). Відмічено поглиблення гіпертензії, котре не потребувало відміни препарату ЕМАВЕЙЛ та корегувалось збільшенням дози антигіпертензивних лікарських засобів. Рівень тромбоцитів крові протягом курсу лікування достовірно не змінився $(214,17 \pm 6,29$ проти $221,36 \pm 2,99, \mathrm{p}$ $>0,05)$. Інші лабораторні показники та показники вітальних функцій, що підлягали контролю, також достовірно не змінювались.

Обговорення. Незважаючи на великі досягнення в лікуванні хронічної хвороби нирок за останні десятиріччя, анемія продовжує залишатися актуальною проблемою в лікуванні діалізних пацієнтів. Застосування біоаналогів еритропоетинів дозволяє ефективно корегувати анемію, разом 3 тим $є$ дешевшим порівняно з використанням оригінальних препаратів.

В нашому дослідженні застосування біоаналогу епоетину альфа ЕМАВЕЙЛ дозволило досягнути цільового значення рівня Нb у $89 \%$ хворих. Це відповідає даним, отриманим в популяційному дослідженні в Італії [8] про високу, порівняну з оригінальними епоетинами, ефективність біоаналогів.

Середня тривалість терапії до досягнення цільового рівня Нb склала 28,44 2,63 днів. А середня тижнева доза ЕМАВЕЙЛ на початку лікування склала $150,48 \pm 1,73 \mathrm{MO} / \mathrm{Kг}$, а в у період корекції

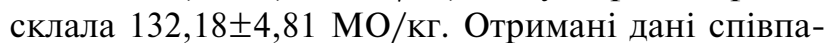
дають з опублікованими даними попередніх досліджень, котрі демонструють, що середня початкова тижнева доза епоетину альфа була приблизно на 40\% вище, ніж кінцева тижнева доза [9].

У представленому дослідженні небажані явища, пов'язані безпосередньо 3 препаратом, реєструвалися вкрай рідко. Найбільш часто відмічено поглиблення гіпертензії, котре не потребувало відміни препарату ЕМАВЕЙЛ та корегувалось збільшенням дози антигіпертензивних лікарських засо- бів. Добре переносили препарат 30 хворих (83\%). Задовільна переносимість констатована у 6 пацієнтів (17\%). Рівень тромбоцитів крові протягом курсу лікування достовірно не змінився $(214,17 \pm 6,29$ проти 221,36 $\pm 2,99, \mathrm{p}>0,05)$. Інші лабораторні показники та показники вітальних функцій, що підлягали контролю, також достовірно не змінювались. За даними попередніх досліджень гіпертензія, що обумовлюється епоетином, являється найбільш поширеним побічним явищем, констатується у 10-30\% гемодіалізних хворих, котрі отримують епоетин, та може мати тяжкий перебіг [10, 11]. Отже, частота побічних явищ за умов використання біоаналогу епотетину альфа ЕМАВЕЙЛ не перевищувала показники, отримані в попередніх дослідженнях з ефективності та безпеки застосування епоетинів.

Висновки. Таким чином, ЕМАВЕЙЛ (епоетин-альфа), розчин для ін'єкцій виробництва Shanyang Sunshine Pharmaceutical Co. Ltd., є ефективним та безпечним засобом корекції анемії у хворих на XXН VД стадії, які лікуються методом гемодіалізу. Застосування ЕМАВЕЙЛ дозволяє досягти цільового рівня Нb у $89 \%$ хворих. Препарат добре переносився 83\% хворих. У $17 \%$ пацієнтів констатоване помірне посилення артеріальної гіпертензії, яке не потребувало зміни схеми лікування. Серйозні побічні явища не відмічені.

Конфлікт інтересів: автори заявляють, що у них немає конфлікту інтересів.

Інформація про внесок кожного учасника:

I.O. Дудар: концепція та дизайн дослідження;

$\boldsymbol{E}$. К. Красюк: оформлення тексту роботи;

F.І. Гонцар: концепція та дизайн дослідження;

O.M. Лобода: аналіз отриманих даних;

I.M. Wiфpic: оформлення тексту роботи;

$\boldsymbol{B . \Phi . ~ K р о т : ~ о ф о р м л е н н я ~ т е к с т у ~ р о б о т и ; ~}$

B. М. Савцук: аналіз отриманих даних.

\section{Література (References):}

1. WHO. Haemoglobin Concentrations for the Diagnosis of Anaemia and Assessment of Severity. Vitamin and Mineral Nutrition Information System. Geneva, Switzerland: WHO; 2011. Available from: https:// www.who.int/vmnis/indicators/haemoglobin.pdf.

2. Palaka $E$, Grandy $S$, van Haalen $H$, McEwan $P$, Darlington $O$. The Impact of CKD Anaemia on Patients: Incidence, Risk Factors, and Clinical Outcomes-A Systematic Literature Review. Int J Nephrol 2020 Jul 1;2020:7692376. doi: $10.1155 / 2020 / 7692376$

3. Hörl WH. Anaemia management and mortality risk in chronic kidney disease. Nat Rev Nephrol.
2013 May;9(5):291-301. doi: 10.1038/nrneph.2013.21

4. Johansen KL, Finkelstein FO, Revicki DA, Evans $C$, Wan S, Gitlin M, Agodoa IL. Systematic review of the impact of erythropoiesis-stimulating agents on fatigue in dialysis patients. Nephrol Dial Transplant. 2012 Jun;27(6):2418-25. doi: 10.1093/ ndt/gfr697.

5. Kamyar Kalantar-Zadeh. History of ErythropoiesisStimulating Agents, the Development of Biosimilars, and the Future of Anemia Treatment in Nephrology. Am J Nephrol. 2017;45:235-247 doi: $10.1159 / 000455387$. 
6. Kolesnyk MO, hol. redaktor. Natsionalnyi reiestr khvorykh na khronichnu khvorobu nyrok ta patsientiv $\mathrm{z}$ hostrym poshkodzhenniam nyrok: 2019 rik / uklad. NI Kozliuk, OO Razvazhaieva; Derzhavna ustanova «Instytut nefrolohii NAMN Ukrainy». Kyiv; 2020.179 s. [In Ukrainian].

7. Kolesnyk $M O$, hol. redaktor. Natsionalnyi reiestr khvorykh na khronichnu khvorobu nyrok : 2013 rik / uklad. N. I. Kozliuk, S. S. Nikolaienko, M. V. Kulyzkyi ; Derzhavna ustanova „Instytut nefrolohii NAMN Ukrainy”. Kyiv; 2014. 200 s. [In Ukrainian].

8. Trotta F, Belleudi V, Fusco D, et al. Comparative effectiveness and safety of erythropoiesis-stimulatingagents (biosimilars vs originators) in clinical practice: a population-basedcohort study in Italy. BMJ
Open. 2017; 7(3): e011637. Published online 2017 Mar 10. doi: 10.1136/bmjopen-2016-011637.

9. Jones M, Ibels L, Schenkel B, Zagari M. Impact of epoetin alfa on clinical end points in patients with chronic renal failure: A meta-analysis. Kidney Int. 2004 Mar;65(3):757-67. doi: 10.1111/j.15231755.2004.00450.x.

10. Krapf $R$, Hulter $H N$. Arterial Hypertension Induced by Erythropoietin and ErythropoiesisStimulating Agents (ESA). Clin J Am Soc Nephrol. 2009 Feb;4(2):470-80. doi: 10.2215/ CJN.05040908.

11. Mary S Lee, John S Lee, Jong Y Lee. Prevention of Erythropoietin-Associated Hypertension. Hypertension. 2007 Aug;50(2):439-45. doi: 10.1161/HYPERTENSIONAHA.107.090423. 